\title{
HEAVY METALS IN RIVERS AFFECTED BY MINING ACTIVITIES IN ECUADOR: POLLUTION AND HUMAN HEALTH IMPLICATIONS
}

\author{
KENNY ESCOBAR-SEGOVIA ${ }^{1,2}$, SAMANTHA JIMÉNEZ-OYOLA ${ }^{1,3}$, DANIEL GARCÉS-LEÓN ${ }^{1}$, \\ DANIELA PAZ-BARZOLA ${ }^{1}$, EDUARDO CHAVEZ NAVARRETE ${ }^{1}$, PAOLA ROMERO-CRESPO ${ }^{1}$ \\ \& BRYAN SALGADO ${ }^{1}$ \\ ${ }^{1}$ Escuela Superior Politécnica del Litoral, Ecuador \\ ${ }^{2}$ Universidad Espíritu Santo, Ecuador \\ ${ }^{3}$ Universidad Politécnica de Madrid, Spain
}

\begin{abstract}
Artisanal and small scale gold mining operations have been an important source of toxic elements in the environment, with possibly negative consequences for ecosystems and human health. This study aims to assess the pollution degree and human health risk due to heavy metals exposure in mining communities. The data correspond to samples collected in rivers located in the vicinity of Ponce Enríquez, one of the most important gold mining sites in Ecuador. The concentrations of $\mathrm{As}, \mathrm{Cd}, \mathrm{Cu}$, $\mathrm{Pb}$, and $\mathrm{Zn}$ were analysed in surface water $(\mathrm{n}=13)$ and sediment $(\mathrm{n}=7)$ samples. Heavy metals contents were compared with (a) the corresponding backgrounds values $\left(\mathrm{B}_{\mathrm{i}}\right)$ and (b) the permissible limits established by the Ecuadorian regulation. Furthermore, the Geo-accumulation Index (Igeo) and Metal Index (MI) were estimated for sediments and surface waters, respectively. Lastly, the potential adverse effects on human health due to the exposure to HMs in polluted rivers were carried out based on the hazard index (HI) and total cancer risk (TCR), using the traditional deterministic approach. The results showed that surface waters and sediments were enriched in heavy metals. The $57 \%$ of the sediment samples showed severe to extremely pollution ( $\mathrm{Igeo}_{\text {ge }}>3$ ) due to the high contents of As and $\mathrm{Cd}$. On the other hand, surface water was in the strongly to seriously affected category (MI $>3$ ) in 23\% of the sample's locations, with $\mathrm{As}, \mathrm{Cu}$ and $\mathrm{Pb}$ as the main contaminants. Likewise, residents exposed to polluted rivers showed $\mathrm{HI}$ and TCR values above the safe exposure threshold $\left(\mathrm{HI}=1\right.$ and $\left.\mathrm{TCR}=10^{5}\right)$, being as the main contributor to the overall risk. Based on the preliminary results found in this research, future rivers monitoring and control efforts are needed to reduce the pollutions levels and the health hazard of the inhabitants of the mining areas.
\end{abstract}

Keywords: mining, pollution, heavy metals, health risk.

\section{INTRODUCTION}

Uncontrolled mining operations are causing serious environmental problems due to the large amount of pollutants generated. These can be introduced into the water system by surface runoff, causing water pollution not only in the mining area but in a larger region [1], [2]. Heavy metal(loid) contamination is known to be harmful for the environment. Presence of contaminants in soils, waters and air can be caused by natural events; however, the anthropogenic activities are the main contributors to the pollution [3]. Mining is one of the most polluting anthropogenic activities, especially in underdeveloped countries, where environmental controls are inadequate [4], [5]. The high concentrations of toxic elements around mining regions causes serious risk to ecosystems and human health [6].

Mining waste may include toxic elements such as $\mathrm{As}, \mathrm{Cd}, \mathrm{Cr}, \mathrm{Ni}$, and $\mathrm{Pb}$, some of them recognized as human carcinogens by the International Agency for Research on Cancer [7], [8]. Exposure to these metals, even in small quantities, can cause significant human-health and ecosystem risks [9], [10]. In Ecuador, inadequate mining practices over the years have caused the environmental degradation of mining environments [11], [12]. Mining processing 
operations have been conducted along rivers and streams [13], discharging mine tailings into streams that eventually flow into rivers [14], [15].

The human health risk depends on the pollutants concentrations in the environmental systems, their toxicity, and the exposure frequency [16]. Furthermore, in countries with tropical weather and very hot seasons like Ecuador, rivers are an important source of enjoyment for the community, especially for the children [17]. Given the elevated levels of exposure of residents have to heavy metal(loid)s and other toxic compounds in the mining communities, the aims of this research were to (a) evaluate the heavy metal(loid) pollution in surface waters and sediments in the Ponce Enríquez mining area, using the Geoaccumulation Index ( $\mathrm{I}_{\text {geo }}$ ) and Metal Index (MI) and (b) assess the human health risks due to exposure to multiple potentially toxic elements present in surface waters, using deterministic approach. The results of this work will provide an insight about the human health risk associated to the pollution in the mining area.

\section{METHODOLOGY}

\subsection{Study area}

Ponce Enríquez is in the southwest part of the country, and the western part of Azuay District (Fig. 1). This area has had massive mining activities since the 1980s [18]. The inadequate and illicit mining practices have caused significant environmental degradation in the area. Most of the mining contamination comes from Cerro Bella Rica and reaches the Siete River through illegal discharges from the treatment plants. Furthermore, mine tailings are stored in technically deficient dumps [15], where acid mine drainage have been lixiviated into soils and streams which eventually discharge into rivers. As a consequence, surface waters and sediments contain high concentration of heavy metals [14], [18]-[21].

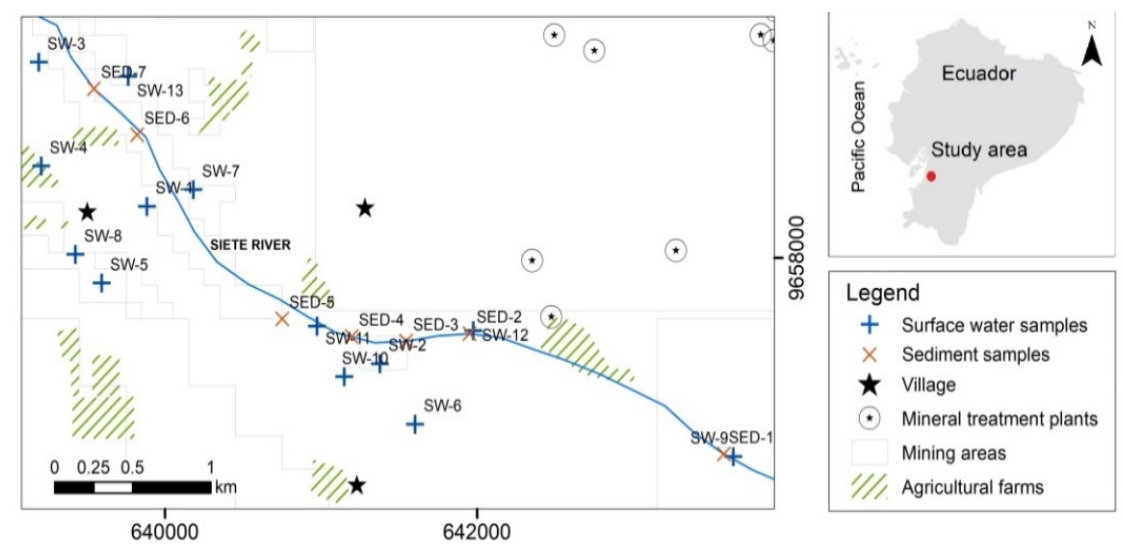

Figure 1: Location of the study area in a national scale, and location of the sampling sites.

\subsection{Data collection and chemical analysis}

The concentrations of $\mathrm{As}, \mathrm{Cd}, \mathrm{Cu}, \mathrm{Pb}$, and $\mathrm{Zn}$ were analysed for 13 surface water samples and 7 sediment samples collected in 2018. The samples came from the Siete River and some surrounding streams. Water samples were acidified with nitric acid and refrigerated until 
analysis. Sediment samples were taken with a Van Veen grab. The samples were sun dried for $48 \mathrm{~h}$ and classifyed to remove impurities. Then, samples were milled and passed through a $2 \mathrm{~mm}$ sieve, to be finally stored in a polyethylene bag prior to analysis.

Heavy metal(loid) concentrations in water samples were determined by Inductively Coupled Plasma Mass Spectroscopy (Agilent 7700x ICP-MS). Certified standard solution concentrations were used to ensure quality results with a standard deviation $<10 \%$. On the other hand, heavy metal concentrations in sediments were analysed by Inductively Coupled Plasma Optical Emission Spectrometry (ICP-OES). For quality control during the analysis, parallel process samples were established as reference material, obtaining relative standard deviations $<5 \%$.

\subsection{Heavy metal(loid) pollution}

\subsubsection{Geo-accumulation index $\left(\mathrm{I}_{\text {geo }}\right)$}

The pollution level of river sediments was quantified with the geo-accumulation index ( $\left.I_{\text {geo }}\right)$ according to eqn (1). This index compares the analytical values of each heavy metal with the geochemical background values [22].

$$
\mathrm{I}_{\text {geo }}=\log _{2}\left[\frac{\mathrm{C}_{\mathrm{i}}}{1.5 \times \mathrm{B}_{\mathrm{i}}}\right] \text {, }
$$

where $C_{i}\left(m g ~ \mathrm{~kg}^{-1}\right)$ is the element $\mathrm{i}$ concentration, and $\mathrm{B}_{\mathrm{i}}\left(\mathrm{mg} \mathrm{L}^{-1}\right)$ is the element $\mathrm{i}$ geochemical background value. The constant 1.5 is used due to possible variations in reference data. The $B_{i}$ values $\left(\mathrm{mg} \mathrm{kg}^{-1}\right)$ used in this study were: $\mathrm{As}=7.7, \mathrm{Cd}=0.17$, $\mathrm{Cu}=60, \mathrm{~Pb}=5.4, \mathrm{Zn}=64$. Those values correspond to sediment samples within the studied area, but in sites which are not affected by mining pollution [23]. The Igeo has seven quality classes: practically unpolluted ( $\left.\mathrm{I}_{\text {geo }} \leq 0\right)$, unpolluted to moderately polluted $\left(0<\mathrm{I}_{\text {geo }}<1\right)$; moderately polluted $\left(1<\mathrm{I}_{\text {geo }}<2\right)$, moderately to heavily polluted $\left(2<\mathrm{I}_{\text {geo }}<3\right)$, heavily polluted $\left(3<\mathrm{I}_{\text {geo }}<4\right)$, heavily to extremely polluted $\left(4<\mathrm{I}_{\text {geo }}<5\right)$; and extremely polluted $\left(\mathrm{I}_{\mathrm{geo}}>5\right)[24]$.

\subsubsection{Metal index (MI)}

The water surface quality was analysed using the metal index (MI) [25], [26]. The MI provides a general understanding of water quality. It has six water quality classifications: very pure $(\mathrm{MI}<0.3)$, pure $(0.3<\mathrm{MI}<1)$; slightly affected $(1<\mathrm{MI}<2)$; moderately affected $(2<\mathrm{MI}<4)$; strongly affected $(4<\mathrm{MI}<6)$; and seriously affected $(\mathrm{MI}>6)$. The MI was calculated with the following eqn (2):

$$
M I=\sum_{i=1}^{N} \frac{C_{i}}{(M A C)_{i}},
$$

where $C_{i}$ is the individual heavy metals concentration of each sample, and MAC is the maximum permissible concentration of the country's metal-based standards. According to the water quality guidelines established by the Ecuadorian legislation: 50, 1, 5, 1, and 30 $\left(\mu \mathrm{g} \cdot \mathrm{L}^{-1}\right)$ were the MAC values used for $\mathrm{As}, \mathrm{Cd}, \mathrm{Cu}, \mathrm{Pb}$ and $\mathrm{Zn}$, respectively [27].

\subsection{Human health risk}

The human health risks assessments were carried out using the Spatial Analysis and Decision Assistance (SADA) software, whose risk models follow the risk assessment guidelines 
proposed by the United States Environmental Protection Agency (USEPA) [28]. The traditional deterministic approach was used due to its simplicity and easy understanding [29]-[31]. This approach assigns a single representative value to each input parameter in the risk equation, leading to a single-value risk output.

For a deterministic approach, the 95\% upper confidence limit (UCL) of the data mean was calculated with the Statistical Software ProUCL 5.1 developed by USEPA [32]. This study considered two kinds of receptors, adults and children; and two kinds of exposure routes: water incidental ingestion and water dermal contact during swimming activities. The received dose (ADD: $\mathrm{mg} \cdot \mathrm{kg}^{-1} \cdot \mathrm{day}^{-1}$ ) of each exposure was calculated using eqns (3) and (4) according with USEPA recommendations [33].

$$
\begin{aligned}
\mathrm{ADD}_{\text {ingestion }} & =\frac{\mathrm{C} \times \mathrm{EF} \times \mathrm{ET} \times \mathrm{IR} \times \mathrm{ED}}{\mathrm{BW} \times \mathrm{AT}}, \\
\mathrm{ADD}_{\text {dermal contact }} & =\frac{\mathrm{C} \times \mathrm{EF} \times \mathrm{ET} \times \mathrm{SA} \times \mathrm{Kp} \times \mathrm{ED}}{\mathrm{BW} \times \mathrm{AT}},
\end{aligned}
$$

where $\mathrm{C}$ value is the water heavy metal concentration $\left(\mu \mathrm{g} \cdot \mathrm{L}^{-1}\right)$; $\mathrm{EF}$ is the annual exposure frequency (days.year ${ }^{-1}$ ); ET is the exposure time (hour.day ${ }^{-1}$ ); IR is the ingestion rate $\left(\mathrm{L} \cdot \mathrm{day}^{-1}\right)$; ED is the life exposure duration (years); SA is the skin surface area exposed $\left(\mathrm{cm}^{2}\right)$; $\mathrm{AF}$ is the adherence factor $\left(\mathrm{mg} \cdot \mathrm{cm}^{-2} \cdot \mathrm{day}^{-1}\right)$; $\mathrm{kp}$ is the skin permeability constant $\left(\mathrm{cm} \cdot \mathrm{hour}^{-1}\right)$; AT is the averaging time (days); and BW is the body weight ( $\mathrm{kg}$ ). The values used in this study were taken from the specific literature and are summarized in Table 1.

\begin{tabular}{|c|c|c|c|}
\hline \multirow{2}{*}{\multicolumn{2}{|c|}{ Parameters }} & \multicolumn{2}{|c|}{ References values } \\
\hline & & Adults & Children \\
\hline $\mathrm{EF}$ & Exposure frequency (days $\cdot$ year $^{-1}$ ) & $60^{3}$ & $60^{3}$ \\
\hline ET & Exposure time (hour $\cdot$ day $^{-1}$ ) & $2.6^{3}$ & $2.6^{3}$ \\
\hline IR & Incidental ingestion of water $\left(\mathrm{L} \cdot \mathrm{day}^{-1}\right)$ & $0.053^{2}$ & $0.090^{2}$ \\
\hline ED & Exposure duration (years) & $30^{1}$ & $6^{1}$ \\
\hline SA & Skin surface area exposed $\left(\mathrm{cm}^{2}\right)$ & $18,400^{3}$ & $6,800^{3}$ \\
\hline $\mathrm{AF}$ & Adherence factor $\left(\mathrm{mg} \cdot \mathrm{cm}^{-2}\right)$ & $0.07^{1}$ & $0.2^{1}$ \\
\hline $\mathrm{kp}$ & Constante de permeabilidad $\left(\mathrm{cm} \cdot\right.$ hour $\left.^{-1}\right)$ & \multicolumn{2}{|c|}{$\mathrm{Zn}=0.0006 ; \mathrm{As}, \mathrm{Cd}, \mathrm{Cu}, \mathrm{Pb}=0.001^{4}$} \\
\hline BW & Body weight (kg) & $72^{3}$ & $15.6^{3}$ \\
\hline \multirow{3}{*}{ AT } & \multicolumn{3}{|c|}{ Averaging time } \\
\hline & Carcinogens (days) & $365 \times \mathrm{ED}^{1}$ & $365 \times \mathrm{ED}^{1}$ \\
\hline & Non-carcinogens (days) & $365 \times 70^{1}$ & $365 \times 70^{1}$ \\
\hline
\end{tabular}

Table 1: Parameters used in the risk assessment.

${ }^{1}$ USEPA [34].

${ }^{2}$ USEPA [16].

${ }^{3}$ Spence and Walden [35].

${ }^{4}$ USDoE [37].

The potential risk of systemic effects was quantified in terms of hazard quotient (HQ) (eqn (5)), which results from dividing the ADD by the reference dose (RfD: $\mathrm{mg} \cdot \mathrm{kg}^{-1} \cdot \mathrm{day}^{-1}$ ). To assess the risks of more than one route of exposure, the Hazard Index (HI) (eqn (6)) was introduced, which is the sum of HQs of all applicable routes of exposure. For HQ and HI above 1 the risk is considered unacceptable [33], [34]. 


$$
\begin{gathered}
\mathrm{HQ}=\frac{\mathrm{ADD}}{\mathrm{RfD}}, \\
\mathrm{HI}=\sum_{\mathrm{i}=1}^{\mathrm{n}} \mathrm{HQ}_{\mathrm{i}} .
\end{gathered}
$$

To characterize the risk for exposure to carcinogenic compounds, the individual probability of develops cancer throughout his life (CR) is established according eqn (7). The $\mathrm{CR}$ is a function of the ADD and the slope factor $\left(\mathrm{SF}:\left(\mathrm{mg} \cdot \mathrm{kg}^{-1} \cdot \mathrm{day}^{-1}\right)^{-1}\right)$, which is the upper limit of the estimate of the increased risk of suffering cancer throughout life due to exposure to a unit dose of the carcinogenic agent. CR was determined for each exposure, and then CRs were summed and expressed as a Total Cancer Risk (TCR) in eqn (8). Finally, the TCR values were compared with the acceptable reference value of $10 \mathrm{E}^{-05}$, where the 1 person developing cancer probability per 100,000 inhabitants exposed is considered [36].

$$
\begin{aligned}
& \mathrm{CR}=\mathrm{ADD} \times \mathrm{SF}, \\
& \mathrm{TCR}=\sum_{\mathrm{i}=1}^{\mathrm{n}} \mathrm{CR}_{\mathrm{i}} .
\end{aligned}
$$

Toxicity data (RfD and SF) were obtained from the Risk Assessment Information System (RAIS) database website [37]. The cancer risk was calculated for As and $\mathrm{Pb}$, elements that have slope factors reported. The overall equations used to calculate the human health risk were implemented in $\mathrm{R}$ language.

\section{RESULTS}

\subsection{Heavy metal(loid) pollution}

The concentration of $\mathrm{As}, \mathrm{Cd}, \mathrm{Cu}, \mathrm{Pb}$ and $\mathrm{Zn}$ in surface waters and sediments are presented in Tables 2 and 3, respectively. In surface waters, high values of $\mathrm{As}, \mathrm{Cu}, \mathrm{Pb}$ and $\mathrm{Zn}$ concentrations exceeding Ecuadorian standards were registered in 55\% of the samples, where $64 \%$ of these occurred in the central part of the study area. Furthermore, SW-11 and SW-13 samples showed very high concentrations of $\mathrm{As}$ and $\mathrm{Cu}$, compared to the other samples and the Ecuadorian regulation. Regarding sediments pollution, this study found elevated heavy metals sediments concentration, mainly $\mathrm{Cd}$ and $\mathrm{As}$, with values up to 600 and 52 times higher than their background values $\left(\mathrm{B}_{\mathrm{i}}\right)$. Cd was above the $\mathrm{B}_{\mathrm{i}}$ in all the sampling locations. The results concur with the informed by other authors [18], [38], who reported elevated heavy metals sediments concentrations in the studied mining area.

\subsubsection{Geo-accumulation index}

The $I_{\text {geo }}$ is an effective tool to characterize the sediment pollution levels by evaluating metal content above background values [22]. Based on $\mathrm{I}_{\text {geo }}$, sediments from the Siete River presented high pollution levels. According to Table 4, 57\% of the samples resulted in heavily to extremely polluted category. The highest $\mathrm{I}_{\text {geo }}$ values were reported for $\mathrm{As}$ and $\mathrm{Cd}$. For $\mathrm{Cu}$, the $\mathrm{I}_{\text {geo }}$ values denoted a moderate to extremely polluted degree. Also, $\mathrm{I}_{\text {geo }}$ values for $\mathrm{Pb}$ ranged from unpolluted to moderate polluted whereas $\mathrm{Zn}$ occurred in unpolluted levels in $42 \%$ of samples $\left(\mathrm{I}_{\mathrm{geo}}<0\right)$. The box plot in Fig. 2 showed a large data dispersion of $\mathrm{I}_{\text {geo }}$ values. The highest $\mathrm{I}_{\text {geo }}$ was reported to $\mathrm{Cd}$, followed by $\mathrm{As}, \mathrm{Cu}, \mathrm{Pb}$ and $\mathrm{Zn}$. The range of values were between -4 and 10 , being As- $\mathrm{I}_{\mathrm{geo}}=-2.94$ the minimum value of the whole set of samples, and $\mathrm{Cd}-\mathrm{I}_{\text {geo }}=8.63$ the maximum estimated value. The $\mathrm{I}_{\text {geo }}$ mean of $\mathrm{Cu}, \mathrm{Pb}$ and $\mathrm{Zn}$ were below 2 (unpolluted to moderately polluted) while the values of $\mathrm{As}$ and $\mathrm{Cd}$ were above level 4; heavily to extremely polluted. 
Table 2: Concentrations of heavy metal in surface water samples $\left(\mathrm{SW}: \mu \mathrm{g} \cdot \mathrm{L}^{-1}\right)$. Values in bold were above the Ecuadorian water quality guidelines.

\begin{tabular}{|c|c|c|c|c|c|}
\hline Samples & $\mathrm{As}$ & $\mathrm{Cd}$ & $\mathrm{Cu}$ & $\mathrm{Pb}$ & $\mathrm{Zn}$ \\
\hline SW-1 & 0.87 & 0.03 & 0.78 & 0.14 & 7.95 \\
\hline SW-2 & 9.33 & 0.04 & 2.43 & 0.96 & 9.06 \\
\hline SW-3 & 12.03 & 0.03 & 2.31 & 0.37 & 8.93 \\
\hline SW-4 & 10.85 & 0.03 & 2.36 & 0.20 & 7.13 \\
\hline SW-5 & 1.36 & 0.01 & 0.40 & 0.06 & 5.68 \\
\hline SW-6 & 0.87 & 0.02 & 0.67 & 0.17 & 11.30 \\
\hline SW-7 & 9.99 & 0.05 & 1.63 & 0.47 & 14.17 \\
\hline SW-8 & 0.90 & 0.03 & 0.68 & 0.09 & 8.65 \\
\hline SW-9 & 5.82 & 0.01 & 0.63 & 0.15 & 5.89 \\
\hline SW-10 & 11.97 & 0.08 & 3.83 & $\mathbf{1 . 0 6}$ & 13.54 \\
\hline SW-11 & $\mathbf{6 2 . 0 4}$ & 0.17 & $\mathbf{2 7 . 2 6}$ & 0.46 & 10.33 \\
\hline SW-12 & 44.60 & 0.29 & $\mathbf{8 . 6 5}$ & 0.69 & 19.62 \\
\hline SW-13 & $\mathbf{2 6 3 . 4 6}$ & 0.80 & $\mathbf{2 9 3 . 9 5}$ & $\mathbf{1 5 4 . 3 2}$ & $\mathbf{9 6 . 5 5}$ \\
\hline
\end{tabular}

Table 3: Concentrations of heavy metal in sediment samples (SED: $\mathrm{mg} \cdot \mathrm{kg}^{-1}$ ). Values in bold were above the background values for sediments.

\begin{tabular}{|l|c|c|c|c|c|}
\hline Samples & $\mathrm{As}$ & $\mathrm{Cd}$ & $\mathrm{Cu}$ & $\mathrm{Pb}$ & $\mathrm{Zn}$ \\
\hline SED-1 & 1.50 & $\mathbf{0 . 2 4}$ & 21.59 & 3.97 & 49.86 \\
\hline SED-2 & 7.14 & $\mathbf{1 . 6 8}$ & $\mathbf{1 0 1 . 1 9}$ & $\mathbf{8 . 3 2}$ & $\mathbf{7 0 . 3 7}$ \\
\hline SED-3 & 4.31 & $\mathbf{0 . 8 9}$ & 42.67 & 2.79 & 45.34 \\
\hline SED-4 & $\mathbf{2 4 0 . 9 7}$ & $\mathbf{6 0 . 6 7}$ & $\mathbf{3 0 8 . 5 2}$ & $\mathbf{1 4 . 0 8}$ & $\mathbf{1 2 1 . 1 4}$ \\
\hline SED-5 & $\mathbf{2 0 1 . 1 9}$ & $\mathbf{5 1 . 5 6}$ & $\mathbf{2 8 5 . 9 3}$ & $\mathbf{1 4 . 3 6}$ & $\mathbf{9 8 . 3 5}$ \\
\hline SED-6 & $\mathbf{4 0 2 . 6 7}$ & $\mathbf{1 0 1 . 1 5}$ & $\mathbf{1 5 6 1 . 3 9}$ & $\mathbf{1 1 4 . 6 1}$ & $\mathbf{3 5 6 . 9 2}$ \\
\hline SED-7 & $\mathbf{2 3 2 . 5 0}$ & $\mathbf{5 7 . 2 5}$ & $\mathbf{1 4 8 0 . 2 1}$ & $\mathbf{4 3 . 3 8}$ & $\mathbf{1 9 5 . 4 3}$ \\
\hline
\end{tabular}

Table 4: Values of Geo-accumulation Index. Values in bold show heavily to extremely pollution.

\begin{tabular}{|l|c|c|c|c|c|}
\hline \multirow{2}{*}{ Samples } & \multicolumn{5}{|c|}{ Geo-accumulation index } \\
\cline { 2 - 6 } & $\mathrm{As}$ & $\mathrm{Cd}$ & $\mathrm{Cu}$ & $\mathrm{Pb}$ & $\mathrm{Zn}$ \\
\hline SED-1 & -2.94 & -0.09 & -2.06 & -1.03 & -0.95 \\
\hline SED-2 & -0.69 & 2.72 & 0.17 & 0.04 & -0.45 \\
\hline SED-3 & -1.42 & 1.80 & -1.08 & -1.54 & -1.08 \\
\hline SED-4 & $\mathbf{4 . 3 8}$ & $\mathbf{7 . 8 9}$ & 1.78 & 0.80 & 0.34 \\
\hline SED-5 & $\mathbf{4 . 1 2}$ & $\mathbf{7 . 6 6}$ & 1.67 & 0.83 & 0.03 \\
\hline SED-6 & $\mathbf{5 . 1 2}$ & $\mathbf{8 . 6 3}$ & $\mathbf{4 . 1 2}$ & 3.82 & 1.89 \\
\hline SED-7 & $\mathbf{4 . 3 3}$ & $\mathbf{7 . 8 1}$ & $\mathbf{4 . 0 4}$ & 2.42 & 1.03 \\
\hline
\end{tabular}




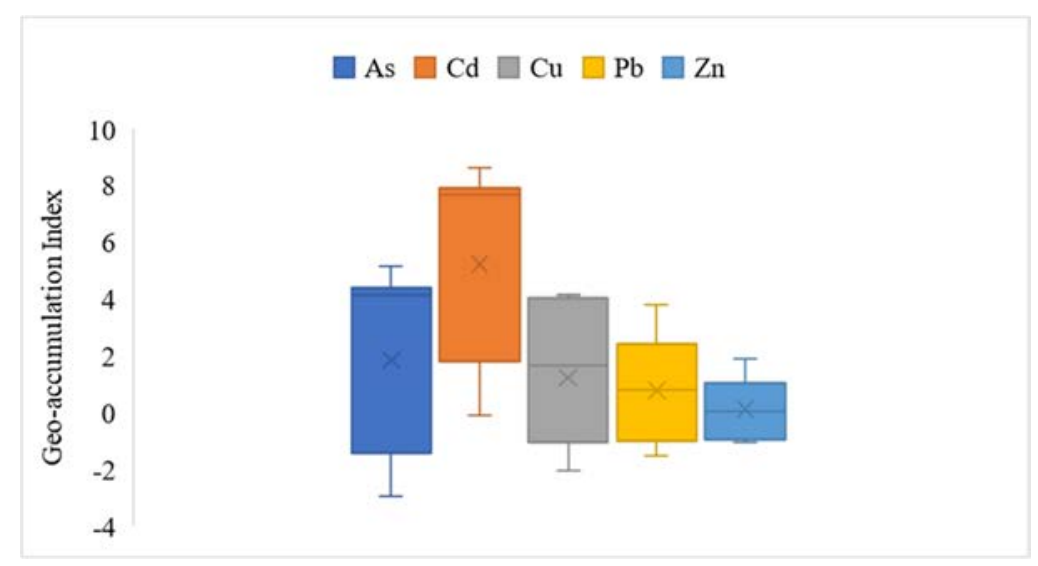

Figure 2: Box plot of $I_{\text {geo }}$ values for sediment samples.

The $\mathrm{I}_{\text {geo }}$ values detected in this study were similar to those reported by Aguilar et al. [20]. Furthermore, the $I_{\text {geo }}$ values in the study area were in the same range as observed in the Colombia, Brazil, Iran and China mining areas [39]-[42], with moderate to severe degree of pollution where As- $\mathrm{Cd}-\mathrm{Cu}$ metals are the most disturbing contaminants. On the other hand, $\mathrm{I}_{\text {geo }}$ for $\mathrm{Pb}$ was significantly lower than the ones reported in other mining areas [43], [44] which could be explained by the geology. Furthermore, lowers Igeo were detected in mining regions in Brazil [45] and India [46], with $I_{g e o}$ values of 4 and 2, respectively.

\subsubsection{Metal index (MI)}

The categorization of water quality based on the metal index is shown in Fig. 3. As a result, $38 \%$ of the samples were pure, the remaining percentage were from slightly to seriously affected. The samples SW-11 and SW-13 were the ones identified as seriously affected. These results evidence the potential impact of mining activities. It is well known that mining wastes in the area usually contains: arsenopyrite, pyrite, pyrrhotite, and sphalerite [11], which may explain the pollution levels in surface waters.

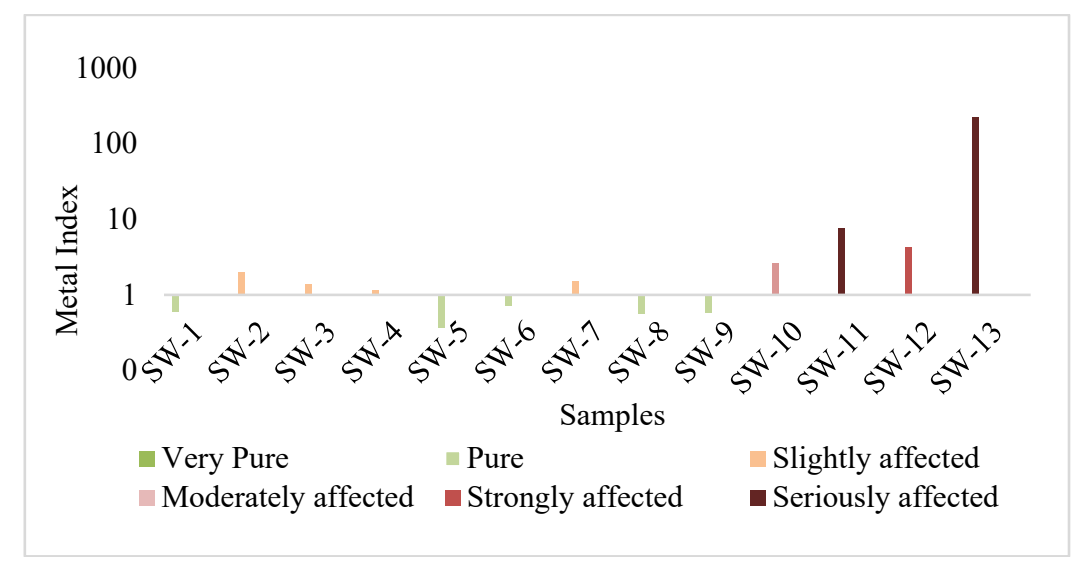

Figure 3: MI column diagram of surface water samples. 


\subsection{Human health implications}

Table 5 shows the outcomes for the carcinogenic (TCR) and non-carcinogenic (HI) risk for adults and children receptors. Surface waters have revealed elevated concentration of heavy metal(loid)s. These elements, especially $\mathrm{As}$ and $\mathrm{Pb}$, represents a significant health hazard for inhabitants. The cumulative non-carcinogenic risk (HI) for children was over the safe exposure limit level $(\mathrm{HI}>1)$ for water incidental ingestion. In contrast, the $\mathrm{HI}$ for adults was below the recommended limit. While As resulted the pollutants of major concern, exposure to $\mathrm{Cd}, \mathrm{Cu}, \mathrm{Pb}$ and $\mathrm{Zn}$ was negligible (HQ values were in order of $10^{-01}$ and $10^{-05}$ ) for both receptors (Fig. 4(a)).

Regarding the carcinogenic risk, the TCR through incidental ingestion of water was above the safe exposure threshold for both adults and children receptors, but it was below the recommended value $\left(10 \mathrm{E}^{-05}\right)$ for dermal contact. In addition, As was the main contributor to the cancer risk level for almost $99.75 \%$ of TCR for both receptors (Fig. 4(b)).

Table 5: Deterministic HI and TCR in surface waters for both receptors.

\begin{tabular}{|c|c|c|c|c|}
\hline \multirow{2}{*}{} & \multicolumn{2}{|c|}{ Ingestion } & \multicolumn{2}{c|}{ Dermal contact } \\
\cline { 2 - 5 } & Adults & Children & Adults & Children \\
\hline HI & $1.60 \mathrm{E}-01$ & $1.27 \mathrm{E}+00$ & $5.64 \mathrm{E}-02$ & $9.62 \mathrm{E}-02$ \\
\hline TCR & $2.89 \mathrm{E}-05$ & $4.53 \mathrm{E}-05$ & $9.80 \mathrm{E}-06$ & $3.42 \mathrm{E}-06$ \\
\hline
\end{tabular}

Children are the most vulnerable receptors; the HI and TCR values for children were almost two times higher than adults values. The exposure to heavy metal(loid)s through polluted waters incidental ingestion was the main cause to the non-carcinogenic and carcinogenic risk for children.

The outcomes in this study were consistent with the informed by other authors in mining areas around the word [3], [39], [42], [47], [48]. Therefore, exposure reduction policies should be adopted to reduce the risk levels to which the population around mining locations is exposed. The frequency of EF exposure used in this study was 60 events $\cdot y e^{-1}{ }^{-1}$. However, under tropical weather like Ecuador, where rivers are used for recreational purposes, EF can increase considerably, mainly for children. Therefore, population-specific parameters should be determined locally to obtain more reliable results.

\section{CONCLUSIONS}

This study reveals the elevated heavy metal concentration in surface waters and sediment samples from the Ponce Enríquez mining area. The 57\% of the sediment samples showed severe to extremely pollution, mainly with the As and Cd elements. Furthermore, 23\% of the water samples were from strongly to seriously affected category, with $\mathrm{As}, \mathrm{Cu}$ and $\mathrm{Pb}$ elements as the main pollutants. The risk outcomes by deterministic methods showed that exposure in local rivers are unsafe for human health. The carcinogenic and non-carcinogenic risk was above the safe exposure limit showing that residents were exposed to an unacceptable risk level, mainly through incidental ingestion of water. The main contributor to the overall risk was As.

This study provides important knowledge about the risk to human health to which the inhabitants of mining communities are exposed. To obtain more realistic results, populationspecific parameters should be determined locally. In addition, a continuous environmental monitoring could help to reduce the pollution in the mining area. 


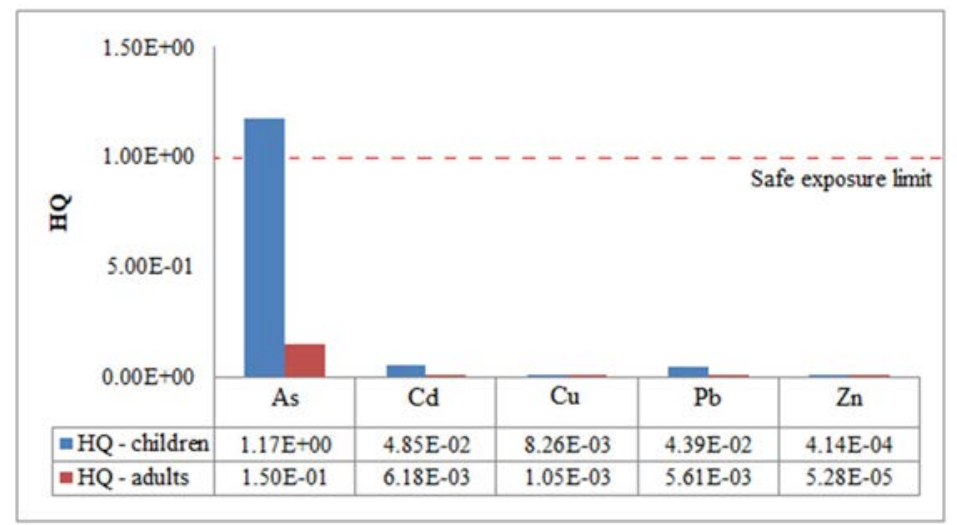

(a)

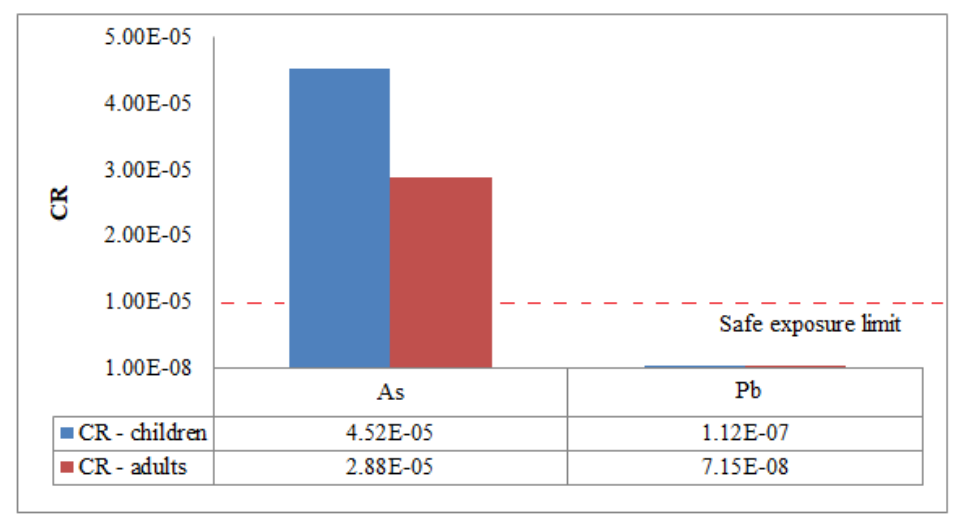

(b)

Figure 4: Heavy metal(loid)s in the human health risk outcomes. (a) Hazard quotient; and (b) Cancer risk.

\section{REFERENCES}

[1] García-Sánchez, A., Alonso-Rojo, P. \& Santos-Francés, F., Distribution and mobility of arsenic in soils of a mining area (Western Spain). Science of the Total Environment, 408(19), pp. 4194-4201, 2010. DOI: 10.1016/j.scitotenv.2010.05.032.

[2] Wu, Y. et al., Migration and transformation of arsenic: Contamination control and remediation in realgar mining areas. Applied Geochemistry, 77, pp. 44-51, 2017. DOI: 10.1016/j.apgeochem.2016.05.012.

[3] Ngole-Jeme V.M. \& Fantke P., Ecological and human health risks associated with abandoned gold mine tailings contaminated soil. PLoS One, 12(2), pp. 1-14, 2018. DOI: 10.1371/journal.pone.0172517.

[4] Bundschuh, J. et al., One century of arsenic exposure in Latin America: A review of history and occurrence from 14 countries. Science of the Total Environment, 429, pp. 2-35, 2012. DOI: 10.1016/j.scitotenv.2011.06.024. 
[5] Vangsnes, G.F., The extractive industries and society the meanings of mining: A perspective on the regulation of artisanal and small-scale gold mining in southern Ecuador. Extractive Industries and Society, 5(2), pp. 317-326, 2018.

DOI: $10.1016 /$ j.exis.2018.01.003.

[6] Rapant, S., Dietzová, Z. \& Cicmanová, S., Environmental and health risk assessment in abandoned mining area, Zlata Idka, Slovakia. Environtal Geology, 51(3), pp. 387397, 2006. DOI: 10.1007/s00254-006-0334-x.

[7] IARC, Evaluation of carcinogenic risk for humans. Lyon, 1987.

[8] Mulware, S.J., Trace elements and carcinogenicity: a subject in review. 3 Biotech, 3(2), pp. 85-96, 2013. DOI: 10.1007/s13205-012-0072-6.

[9] WHO, Guidelines for Drinking-Water Quality, 4th edn, 2011.

[10] USEPA, 2018 Edition of the Drinking Water Standards and Health Advisories Tables, Washington, DC, 2018. DOI: EPA 822-S-12-001.

[11] Peña-Carpio, E. \& Menéndez-Aguado, J.M., Environmental study of gold mining tailings in the Ponce Enriquez mining area (Ecuador). Dyna, 83(195), pp. 237-245, 2016. DOI: 10.15446/dyna.v83n195.41745.

[12] Velásquez-López, P.C., Veiga, M.M. \& Hall, K., Mercury balance in amalgamation in artisanal and small-scale gold mining: Identifying strategies for reducing environmental pollution in Portovelo-Zaruma, Ecuador. Journal of Cleaner Production, 18(3), pp. 226-232, 2010. DOI: 10.1016/j.jclepro.2009.10.010.

[13] Williams, T.M. et al., Regional geochemical reconnaissance of the Cordillera Occidental of Ecuador: Economic and environmental applications. Applied Geochemistry, 15(4), pp. 531-550, 2000. DOI: 10.1016/S0883-2927(99)00059-1.

[14] Carling, G.T. et al., Particulate and dissolved trace element concentrations in three southern Ecuador rivers impacted by artisanal gold mining. Water, Air, and Soil Pollution, 224(2), 2013. DOI: 10.1007/s11270-012-1415-y.

[15] Jordá, R., Romero, P., Peña, E., Jiménez, S., Garcés, D. \& Chang R., Análisis preliminar de la estabilidad de escombreras y balsa de relaves en el Distrito Minero Ponce Enríquez, Ecuador, pp. 19-21, 2017.

[16] USEPA, Exposure Factors Handbook: 2011 Edition, Washington, DC, 2011.

[17] MAE-PRAS, Ministerio de Ambiente de Ecuador. Programa de Reparación Integral de la zona de estudio Tenguel - Camilo Ponce Enríquez. Quito, 2015.

[18] Appleton, J.D., Williams, T.M., Orbea, H. \& Carrasco, M., Fluvial contamination associated with artisanal gold mining in the Ponce Enríquez, Portovelo-Zaruma and Nambija areas, Ecuador. Water, Air, and Soil Pollution, 131(1-4), pp. 19-39, 2001. DOI: 10.1023/A:1011965430757.

[19] Appleton, J., Carrasco, M., Maldonado, R. \& Orbea, H., Assessment of mercury contamination in the Ponce Enriquez artisanal gold mining area, Ecuador. British Geological Survey, 1996.

[20] Aguilar, A., Vitvar, T. \& Peña-Carpio, E., A Multi-index analysis approach to heavy metal pollution in river sediments in the ponce enríquez Area, Ecuador. Water, 11(590), 2019. DOI: 10.3390/w11030590.

[21] Tarras-Wahlberg, N.H., Flachier, A., Lane, S.N. \& Sangfors, O., Environmental impacts and metal exposure of aquatic ecosystems in rivers contaminated by small scale gold mining: The Puyango River basin, southern Ecuador. Science of the Total Environment, 278(1-3), pp. 239-261, 2001.

[22] Muller, G., Index of geoaccumulation in sediments of the Rhine river. GeoJournal, 2, pp. 108-118, 1969. 
[23] PRODEMINCA, Monitoreo Ambiental de las areas mineras en el sur del Ecuador. Ministerio de Energía y Minas, 1998.

[24] Wang, Y. et al., Assessment of multiple exposure to chemical elements and health risks among residents near Huodehong lead-zinc mining area in Yunnan, Southwest China. Chemosphere, 174, pp. 613-627, 2017. DOI: 10.1016/j.chemosphere.2017.01.055.

[25] Withanachchi, S.S. et al., Water quality in surface water: A preliminary assessment of heavy metal contamination of the Mashavera river, Georgia. International Journal of Environmental Research and Public Health, 15(4), pp. 1-25, 2018. DOI: 10.3390/ijerph15040621.

[26] Tamasi, G. \& Cini, R., Heavy metals in drinking waters from Mount Amiata (Tuscany, Italy). Possible risks from arsenic for public health in the Province of Siena. Science of the Total Environment, 327(1-3), pp. 41-51, 2004.

DOI: $10.1016 /$ j.scitotenv.2003.10.011.

[27] MAE-TULSMA, Texto Unificado de Legislación Secundaria Medio Ambiental. Ministerio de Ambiente de Ecuador. Quito, 2015.

[28] University of Tennessee, SADA. Spatial analysis and decision assistance. Tennessee, 2005.

[29] Jiménez-Oyola, S. et al., Multi-pathway human exposure risk assessment using Bayesian modeling at the historically largest mercury mining district. Ecotoxicology and Environmental Safety, 201(March), pp. 110833, 2020.

DOI: 10.1016/j.ecoenv.2020.110833.

[30] Saha, N., Rahman, M.S., Ahmed, M.B., Zhou, J.L., Ngo, H.H. \& Guo, W., Industrial metal pollution in water and probabilistic assessment of human health risk. Journal of Environtal Management, 185, pp. 70-78, 2017. DOI: 10.1016/j.jenvman.2016.10.023.

[31] Jiménez-Oyola, S. et al., Análisis espacial del riesgo para la salud por exposición a metales pesados en el campo minero Ponce Enríquez. pp. 24-26, 2019.

DOI: $10.18687 /$ laccei2019.1.1.117.

[32] EPA, ProUCL statistical support software for site investigation and evaluation. Environmental Protection Agency, p. 1, 2016.

[33] USEPA, Risk assessment guidance for superfund volume I: Human health evaluation manual (Part F). Supplemental Guidance for Inhalation Risk Assessment, Washington, DC, 2009.

[34] USEPA, Risk assessment guidance for superfund volume I: Human health evaluation manual (Part E). Supplemental Guidance for Dermal Risk Assessment, Washington, DC, 2004.

[35] Spence, L.R. \& Walden, T., RISC User's Manual Version 4.0. p. 463, 2001.

[36] USEPA, Guidelines for carcinogen risk assessment, Washington, DC, 2005.

[37] USDoE, U.S. Department of Energy, RAIS: Risk Assessment Information System. 2020.

[38] Tarras-Wahlberg, N., Flachier, A., Fredriksson, G., Lane, S., Lundberg, B. \& Sangfors, O., Environmental impact of small-scale and artisanal gold mining in southern Ecuador. AMBIO Journal of Human Environment, 29(August), pp. 484-491, 2000. DOI: $10.1639 / 0044-7447(2000) 029$.

[39] Alonso, D.L., Pérez, R., Okio, C.K.Y.A. \& Castillo, E., Assessment of mining activity on arsenic contamination in surface water and sediments in southwestern area of Santurbán paramo, Colombia. Journal of Environmental Management, 264(February), 2020. DOI: 10.1016/j.jenvman.2020.110478. 
[40] Yasami, N., Ghaderi, M. \& Taghilou, B., Heavy metal assessment in stream sediments from the rivers passing through the mining area. International Journal of Environmental Science and Technology, 16(0123456789), pp. 1-20, 2018. DOI: 10.1007/s13762-018-1840-6.

[41] Zhang, Z., Lu, Y., Li, H., Tu, Y., Liu, B. \& Yang, Z., Assessment of heavy metal contamination, distribution and source identification in the sediments from the Zijiang River, China. Science of the Total Environment, 645, pp. 235-243, 2018. DOI: 10.1016/j.scitotenv.2018.07.026.

[42] Santos de Souza, E. et al., Assessment of risk to human health from simultaneous exposure to multiple contaminants in an artisanal gold mine in Serra Pelada, Pará, Brazil. Science of the Total Environment, 576, pp. 683-695, 2017.

DOI: $10.1016 /$ j.scitotenv.2016.10.133.

[43] El Azhari, A., Rhoujjati, A., El Hachimi, M.L. \& Paul Ambrosi, J., Pollution and ecological risk assessment of heavy metals in the soil-plant system and the sedimentwater column around a former $\mathrm{Pb} / \mathrm{Zn}$-mining area in NE Morocco. Ecotoxicology and Environmental Safety, 144(June), pp. 464-474, 2017.

DOI: 10.1016/j.ecoenv.2017.06.051.

[44] Kusin, F.M., Azani, N.N.M., Hasan, S.N.M.S. \& Sulong, N.A., Distribution of heavy metals and metalloid in surface sediments of heavily-mined area for bauxite ore in Pengerang, Malaysia and associated risk assessment. Catena, 165, pp. 454-464, 2018. DOI: $10.1016 /$ j.catena.2018.02.029.

[45] Salomão, G.N. et al., Geochemical mapping and background concentrations of iron and potentially toxic elements in active stream sediments from Carajás, Brazil Implication for risk assessment. Journal of South American Earth Sciences, 92(February), pp. 151-166, 2019. DOI: 10.1016/j.jsames.2019.03.014.

[46] Raj, D., Chowdhury, A. \& Maiti, S.K., Ecological risk assessment of mercury and other heavy metals in soils of coal mining area: A case study from the eastern part of a Jharia coal field, India. Human and Ecological Risk Assessment, 23(4), pp. 767-787, 2017. DOI: 10.1080/10807039.2016.1278519.

[47] Chen, G., Wang, X., Wang, R. \& Liu, G., Health risk assessment of potentially harmful elements in subsidence water bodies using a Monte Carlo approach: An example from the Huainan coal mining area, China. Ecotoxicology and Environmental Safety, 171(December 2018), pp. 737-745, 2019. DOI: 10.1016/j.ecoenv.2018.12.101.

[48] Pavilonis, B., Grassman, J., Johnson, G., Diaz, Y. \& Caravanos, J., Characterization and risk of exposure to elements from artisanal gold mining operations in the Bolivian Andes. Environmental Research, 154(August 2016), pp. 1-9, 2017.

DOI: 10.1016/j.envres.2016.12.010. 